\title{
Monitoring of TDS and conductivity in groundwater in the seismically active region in NW Himalayas, India*
}

\author{
Arvind Kumar ${ }^{1}$ Surinder Singh ${ }^{1, \star} \quad$ Bikramjit Singh Bajwa $^{1}$ \\ Sandeep Mahajan $^{1} \quad$ Rajeev Kalia $^{1}$ and Sunil Dhar $^{2}$ \\ ${ }^{1}$ Department of Physics, Guru Nanak Dev University, Amritsar 143005, India \\ ${ }^{2}$ Department of Geology, Govt. College, Dharamsala, Himachal Pradesh 176215, India
}

\begin{abstract}
Key words: TDS (total dissolved solids); conductivity; earthquake precursor; NW Himalayas
\end{abstract}
CLC number: P315.72 3 Document code: A

The earthquake precursors and earthquake prediction are the burning issue among the community of earth scientists and engineers. Studies of earthquake precursory phenomena since the last several decades have shown that significant geophysical and geochemical changes may occur prior to intermediate and large earthquakes (Hartmann and Levy, 2005; Yang et al, 2005; Einarsson et al, 2008; Italiano et al, 2008; Kumar et al, 2009). Among the more intensely investigated geochemical phenomena there have been changes in the concentrations of dissolved ions and gases in groundwater as well as variations in the concentrations of crustal and mantle volatiles in ground gases. Some work on resistivity and TDS (total dissolved solids) measurement in water has been reported (Kayal and Banerjee, 1987; Narayanpethkar et al, 2001; Gupta and Deshpande, 2003). The variation of direct current apparent resistivity has played a prominent role in the prediction of earthquakes (Barsukov 1972; Yamazaki, 1975; Qian, 1984; Sidorenko et al, 1984). Mazzella and Morrison (1974) reported a 24 percent change in apparent resistivity values before an earthquake with $M_{\mathrm{L}} 3.9$ on the San Andreas fault in California. Sidorenko et al (1984) reported a 40-50 percent decrease in effective resistivity before individual, as well as groups of, earthquakes in the former USSR.

In the present investigations, the program of daily monitoring of conductivity and TDS in natural groundwater was initiated for the first time at Amritsar, Dharamshala and Dalhousie (Figure 1) of NW Himalayas, India on December of 2006 to check the suitability of conductivity and TDS as an earthquake precursor.

\footnotetext{
* Received 7 September 2009; accepted in revised form 22 March 2010; published 10 June 2010.

* Corresponding author. e-mail: surinder_s1951@yahoo.co.in

(C) The Seismological Society of China and Springer-Verlag Berlin Heidelberg 2010
}

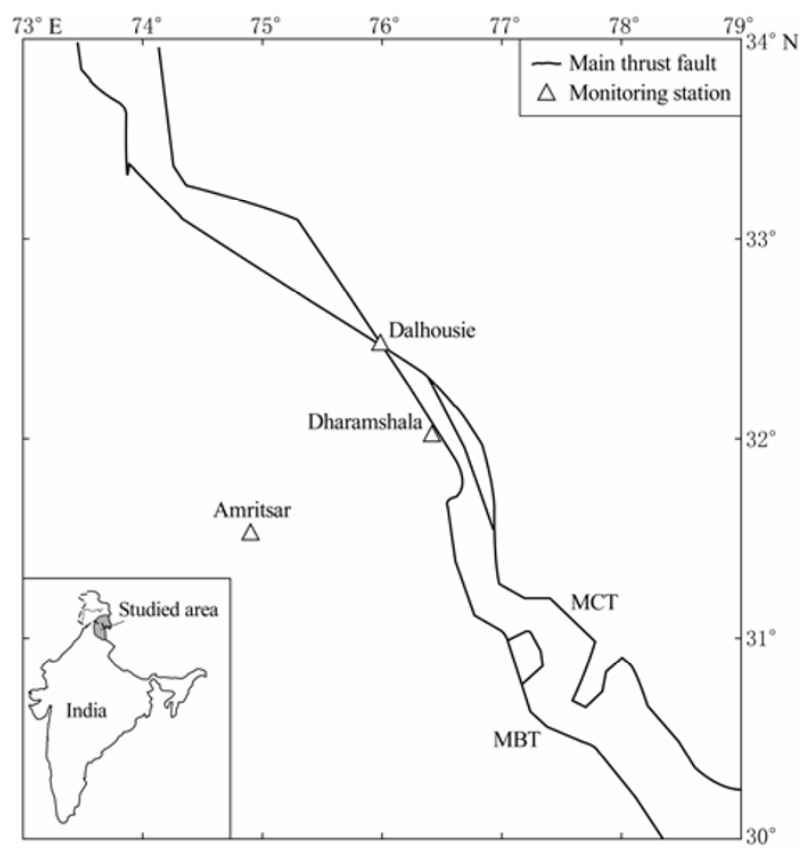

Figure 1 Map showing the location of monitoring stations in NW Himalayas, India, where MCT denotes main central thrust, and MBT denotes main boundary thrust.

\section{Geology of the studied area}

The Himalayas formed by the continent-continent collision between Indian and Eurasian plates are well known for high seismic activity (Walia et al, 2005). Some of the strongest earthquakes in history such as Kangra earthquake of 1905, Bihar Nepal of 1934, great Indian earthquake of 1897 and Assam earthquake of 1950 occurred in the vicinity of Himalaya as a consequence of 
underthrusting of the Indian plate. The Himalayan mountain range, an outcome of the compressional process ensued by the India-Asia collision (70-40 Ma) has undergone extensive crustal shortening along the entire $2400 \mathrm{~km}$ long range. A series of major thrust planes, main central thrust (MCT), main boundary thrust (MBT) and main frontal thrust (MFT) have been formed as a result of these processes.

Narula (1992) divided the main longitudinal N-W Himalayan seismic zone into discrete seismotectonic segments with well-defined transverse boundaries marked by interpretative fundamental faults. These segments are the Kashmir block, Chamba-Kishtwar block, Kangra block, Shimla block, Garhwal block and Kumaon block. The segmentation boundaries might act as earthquake nucleation sites with rupture propagation only in one direction along the longitudinal seismic source. Kangra and Chamba valleys both lie in the Kangra block. The Kangra valley is enclosed between the middle Siwaliks and the Dhauladhar range and the Chamba valley is enclosed between Pir Panjal and Dhauladhar ranges of Lesser Himalaya. Palampur is situated to the south of MBT while Dalhousie to the north side of it. Dalhousie station is situated in the vicinity of MBT, where the MBT and MCT merge into each other.

\section{Experiment technique}

For the measurement of conductivity and TDS, a water sample is collected daily from natural groundwater source in
Dharamshala, Banikhet and Amritsar. The water sources at Dharamshala, Banikhet and Amritsar are $85 \mathrm{~m}, 30 \mathrm{~m}$ and $80 \mathrm{~m}$ in depth, respectively. Water quality kit is used to monitor daily conductivity and TDS in groundwater. Its conductivity range is $0-200 \mathrm{mS} / \mathrm{m}$, resolution $0.1 \mu \mathrm{S} / \mathrm{m}$ and accuracy is $\pm 0.5 \%$ of range \pm 1 digit and TDS measurement range is 0 to $200 \mathrm{ng} / \mathrm{kg}$, resolution is $0.1 \mathrm{mg} / \mathrm{kg}$.

\section{Results and discussion}

The daily variation of conductivity recorded at Amritsar, Dharamshala and Dalhousie from December 2006 to December 2007 is shown in Figure 2. The average conductivity observed during this time window at Amritsar is $0.57 \mathrm{mS} / \mathrm{m}$ with standard deviation 0.04 , at Dharamshala is $0.31 \mathrm{mS} / \mathrm{m}$ with standard deviation 0.07 and at Dalhousie is $0.26 \mathrm{mS} / \mathrm{m}$ with standard deviation 0.03 , respectively. The daily variation of TDS recorded at Amritsar, Dharamshala and Dalhousie from December 2006 to December 2007 is shown in Figure 3. The average TDS observed during this time window at Amritsar is $0.29 \mathrm{ng} / \mathrm{kg}$ with standard deviation 0.02 , at Dharamshala is $137.06 \mathrm{ng} / \mathrm{kg}$ with standard deviation 22.86 and at Dalhousie is $130.21 \mathrm{ng} / \mathrm{kg}$ with standard deviation 22.03, respectively.

Table 1 shows the seasonal average and standard deviation value of conductivity \& TDS at Amritsar, Dharamshala and Dalhousie, respectively. To minimize the seasonable effect if any on conductivity and TDS, the seasonal average value and standard
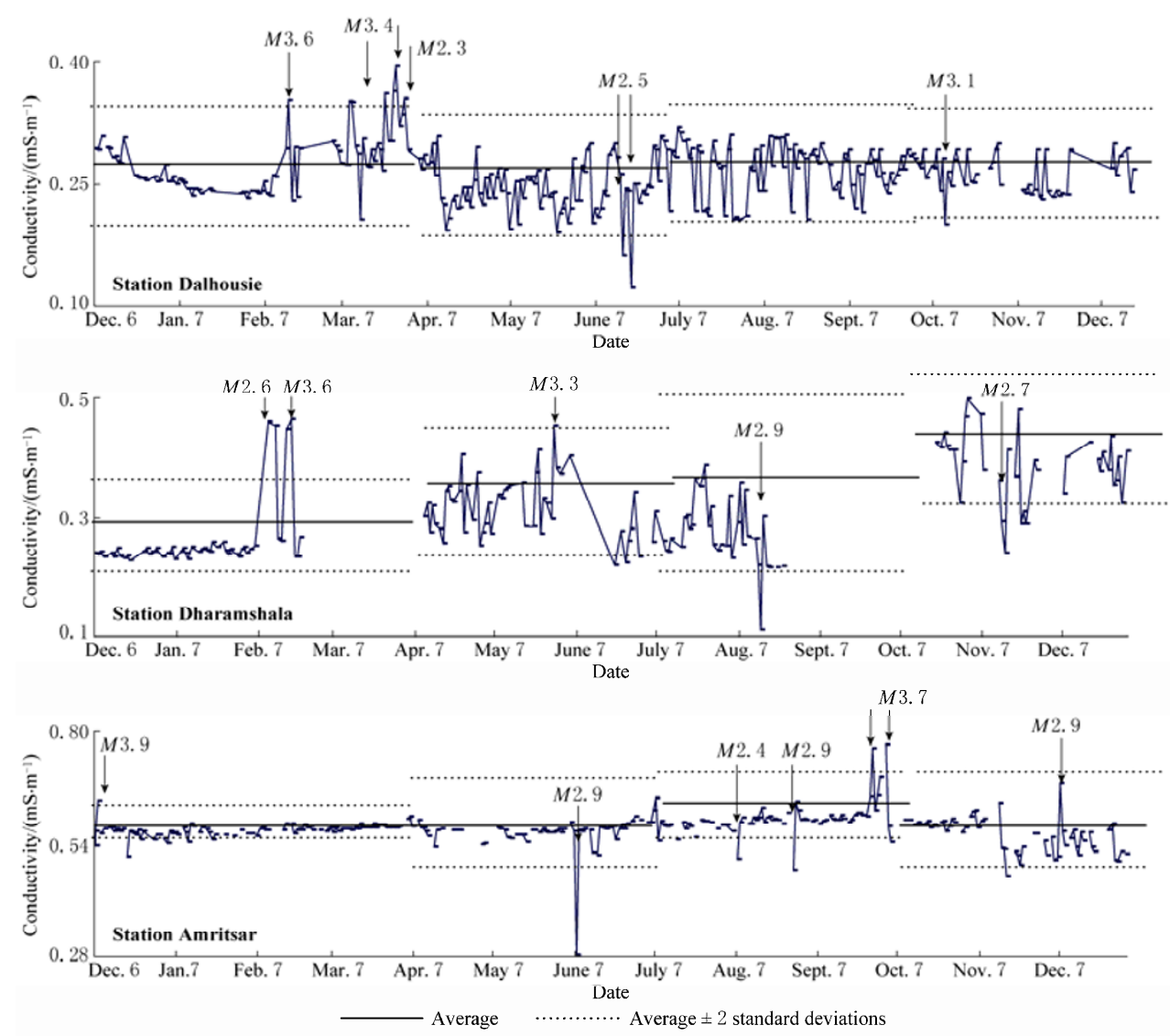

Figure 2 Daily variation of conductivity in groundwater at stations Amritsar, Dharamshala and Dalhousie. 


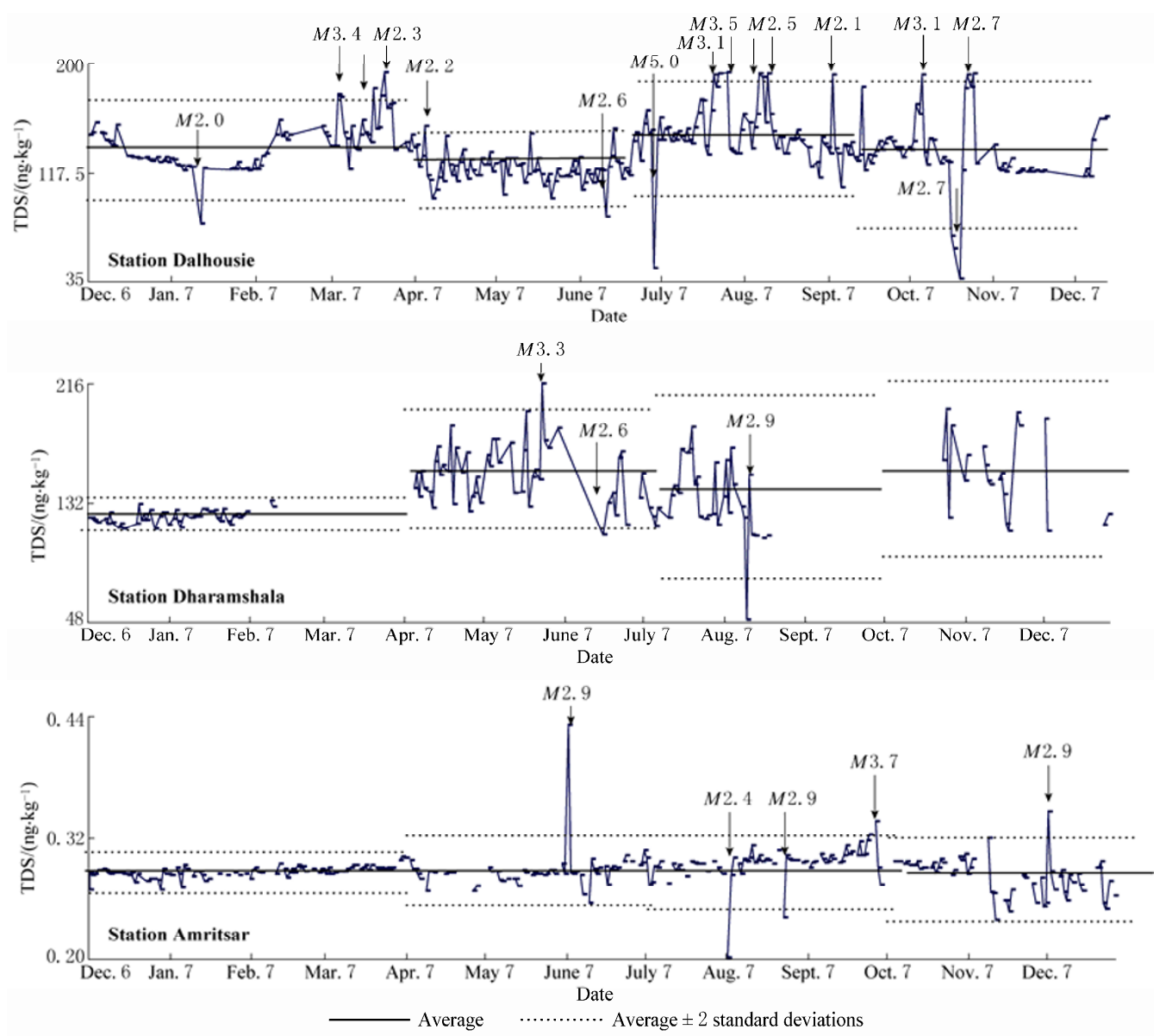

Figure 3 Daily variation of TDS in groundwater at stations Amritsar, Dharamshala and Dalhousie.

Table 1 Seasonal average and standard deviation value of conductivity and TDS at Amritsar, Dharamshala and Dalhousie

\begin{tabular}{|c|c|c|c|c|c|c|c|c|c|}
\hline \multirow[b]{2}{*}{ Period } & \multicolumn{3}{|c|}{ Conductivity at Amritsar/(mS $\left.\cdot \mathrm{m}^{-1}\right)$} & \multicolumn{3}{|c|}{ Conductivity at Dharamshala $/\left(\mathrm{mS} \cdot \mathrm{m}^{-1}\right)$} & \multicolumn{3}{|c|}{ Conductivity at Dalhousie $/\left(\mathrm{mS} \cdot \mathrm{m}^{-1}\right)$} \\
\hline & Average & $\begin{array}{l}\text { Standard } \\
\text { deviation }\end{array}$ & $\begin{array}{c}\text { Variation } \\
\text { coefficient }\end{array}$ & Average & $\begin{array}{l}\text { Standard } \\
\text { deviation }\end{array}$ & $\begin{array}{c}\text { Variation } \\
\text { coefficient }\end{array}$ & Average & $\begin{array}{l}\text { Standard } \\
\text { deviation }\end{array}$ & $\begin{array}{c}\text { Variation } \\
\text { coefficient }\end{array}$ \\
\hline 2006-12-2007-03 & 0.57 & 0.01 & $3.1 \%$ & 0.23 & 0.06 & $26.9 \%$ & 0.27 & 0.04 & $14.8 \%$ \\
\hline 2007-04-2007-06 & 0.57 & 0.04 & $7.0 \%$ & 0.32 & 0.05 & $16.7 \%$ & 0.25 & 0.04 & $16.0 \%$ \\
\hline 2007-07-2007-09 & 0.60 & 0.03 & $5.0 \%$ & 0.33 & 0.08 & $26.7 \%$ & 0.27 & 0.03 & $11.1 \%$ \\
\hline 2007-10-2007-11 & 0.56 & 0.05 & $8.9 \%$ & 0.39 & 0.06 & $15.4 \%$ & 0.26 & 0.02 & $7.7 \%$ \\
\hline \multirow[b]{2}{*}{ Period } & \multicolumn{3}{|c|}{ TDS at Amritsar/ $\left(\mathrm{ng} \cdot \mathrm{kg}^{-1}\right)$} & \multicolumn{3}{|c|}{ TDS at Dharamshala $/\left(\mathrm{ng} \cdot \mathrm{kg}^{-1}\right)$} & \multicolumn{3}{|c|}{ TDS at Dalhousie/(ng. $\left.\mathrm{kg}^{-1}\right)$} \\
\hline & Average & $\begin{array}{r}\text { Standard } \\
\text { deviation }\end{array}$ & $\begin{array}{c}\text { Variation } \\
\text { coefficient }\end{array}$ & Average & $\begin{array}{l}\text { Standard } \\
\text { deviation }\end{array}$ & $\begin{array}{c}\text { Variation } \\
\text { coefficient }\end{array}$ & Average & $\begin{array}{l}\text { Standard } \\
\text { deviation }\end{array}$ & $\begin{array}{c}\text { Variation } \\
\text { coefficient }\end{array}$ \\
\hline 2006-12-2007-03 & 0.29 & 0.01 & $3.5 \%$ & 122.23 & 4.57 & $3.7 \%$ & 136.74 & 17.42 & $12.7 \%$ \\
\hline 2007-04-2007-06 & 0.29 & 0.02 & $6.9 \%$ & 153.70 & 21.42 & $13.9 \%$ & 122.24 & 14.37 & $11.8 \%$ \\
\hline 2007-07-2007-09 & 0.29 & 0.02 & $6.9 \%$ & 141.14 & 27.40 & $19.4 \%$ & 145.30 & 21.82 & $15.0 \%$ \\
\hline 2007-10-2007-11 & 0.28 & 0.02 & $7.1 \%$ & 152.23 & 28.42 & $18.7 \%$ & 132.28 & 28.00 & $21.2 \%$ \\
\hline
\end{tabular}

deviation is calculated and taken into consideration to analyze the data. The four seasons, viz., winter (December-March), summer (April-June), rainy (July-September) and autumn (October-November) are considered in one year. In the present investigations the statistical threshold value of anomalies is fixed at the average plus two standard deviations $(2 \sigma)$ for positive anomaly and average minus two standard deviations $(2 \sigma)$ for negative anomaly, and the seismic events of magnitude $\geq 2$ within the epi- central distance of $250 \mathrm{~km}$ from the monitoring site are correlated. In the case of spatially and temporally clustered earthquakes, the largest earthquake is assumed to precede the anomaly (Hartmann and Levy, 2005). The magnitude of the all earthquakes is in $M_{\mathrm{L}}$.

Table 2 shows the number of conductivity anomalies observed at Amritsar, Dharamshala and Dalhousie during this time window. Out of the observed conductivity anomalies in the studied area, seven at Amritsar, five at Dharamshala and eight at Dal- 
housue; three and five anomalies are positive respectively at these stations whereas the remaining are negative. The conductivity anomalies observed in groundwater are correlated with the seismic events of M2.1-3.9 in the range of epicentral distance $\leq 227$ $\mathrm{km}$ from the monitoring stations. The conductivity shows a negative anomalous value before the NW Himalayas event of magnitude 2.9 that occurred on August 28, 2007 at two stations, viz., Amritsar and Dharamshala. The positive anomalous behavior of the conductivity was also observed at two stations (Dharamshala and Dalhousie) prior to a NW Himalayas earthquake of magnitude 3.6 that occurred on February 21, 2007.

Table 3 shows the number of the TDS anomalies observed at Amritsar, Dharamshala and Dalhousie. Out of the observed TDS anomalies, five at Amritsar, three at Dharamshala and fifteen at Dalhousue; three, one and eleven anomalies are positive respectively at these stations and the remaining are negative. The TDS anomalies observed in ground water are correlated with the M2.1-5.0 seismic events in the range of epicentral distance $\leq 230 \mathrm{~km}$ from the

Table 2 Correlation of conductivity anomalies recorded in groundwater at Amritsar, Dharamshala and Dalhousie with seismic event

\begin{tabular}{|c|c|c|c|c|c|c|c|c|}
\hline Station & Date of anomaly & Date of event & $\begin{array}{l}\text { Lat. } \\
{ }^{\circ} \mathrm{N}\end{array}$ & $\begin{array}{l}\text { Long. } \\
/^{\circ} \mathrm{E}\end{array}$ & $\begin{array}{l}\text { Depth } \\
/ \mathrm{km}\end{array}$ & $M$ & $\begin{array}{c}\text { Epicentral } \\
\text { distance/km }\end{array}$ & $\begin{array}{l}\text { Variation from } \\
\qquad(\operatorname{Avg} \pm 2 \sigma)\end{array}$ \\
\hline \multirow[t]{7}{*}{ Amritsar } & 2006-12-07 & $2006-12-10$ & 31.6 & 77.1 & 10.0 & 3.9 & 189 & $6.7 \%$ \\
\hline & $2007-06-06 *$ & 2007-06-14 & 32.6 & 76.5 & 23.7 & 2.9 & 172 & $4.2 \%$ \\
\hline & 2007-08-06* & $2007-08-13$ & 31.6 & 77.2 & 2.5 & 2.4 & 199 & $5.7 \%$ \\
\hline & $2007-08-27 *$ & $2007-08-28$ & 30.7 & 76.1 & 14.8 & 2.9 & 138 & $9.4 \%$ \\
\hline & $2007-09-26$ & 2007-10-04 & 32.5 & 76.2 & 4.5 & 3.7 & 144 & $13.4 \%$ \\
\hline & 2007-10-01 & & & & & & & $14.9 \%$ \\
\hline & $2007-12-06$ & $2007-12-06$ & 32.5 & 76.3 & & 2.9 & 151 & $4.5 \%$ \\
\hline \multirow[t]{5}{*}{ Dharamshala } & $2007-02-10$ & $2007-02-11$ & 31.6 & 77.2 & 10.0 & 2.6 & 108 & $24.3 \%$ \\
\hline & 2007-02-19 & $2007-02-21$ & 31.4 & 77.6 & 33.0 & 3.6 & 152 & $24.3 \%$ \\
\hline & $2007-05-29$ & $2007-06-03$ & 31.4 & 77.9 & 22.3 & 3.3 & 175 & $7.1 \%$ \\
\hline & $2007-08-15^{*}$ & $2007-08-28$ & 30.7 & 76.1 & 14.8 & 2.9 & 167 & $35.2 \%$ \\
\hline & $2007-11-15^{*}$ & $2007-11-27$ & 31.5 & 77.5 & 6.2 & 2.7 & 137 & $11.1 \%$ \\
\hline \multirow[t]{8}{*}{ Dalhousie } & $2007-02-20$ & $2007-02-21$ & 31.4 & 77.6 & 33.0 & 3.6 & 201 & $2.9 \%$ \\
\hline & 2007-03-15 & $2007-03-30$ & 31.9 & 77.3 & 6.5 & 3.4 & 145 & $2.9 \%$ \\
\hline & 2007-03-27 & & & & & & & $5.9 \%$ \\
\hline & 2007-03-31 & $2007-03-31$ & 31.5 & 77.4 & 10.0 & 2.3 & 180 & $14.7 \%$ \\
\hline & 2007-04-03 & 2007-04-07 & 31.3 & 77.3 & 3.9 & 2.1 & 189 & $2.9 \%$ \\
\hline & $2007-06-21^{*}$ & $2007-06-29$ & 31.6 & 78.1 & 33.5 & 2.5 & 227 & $23.8 \%$ \\
\hline & $2007-06-24 *$ & & & & & & & $42.8 \%$ \\
\hline & $2007-10-16^{*}$ & 2007-10-19 & 32.1 & 76.2 & 17.3 & 3.1 & 59 & $4.8 \%$ \\
\hline
\end{tabular}

*Negative anomaly.

Table 3 Correlation of TDS anomalies recorded in groundwater at Amritsar, Dharamshala and Dalhousie with seismic event

\begin{tabular}{|c|c|c|c|c|c|c|c|c|}
\hline Station & Date of anomaly & Date of event & $\begin{array}{l}\text { Lat. } \\
{ }^{\circ} \mathrm{N}\end{array}$ & $\begin{array}{l}\text { Long. } \\
/{ }^{\circ} \mathrm{E}\end{array}$ & $\begin{array}{l}\text { Depth } \\
/ \mathrm{km}\end{array}$ & $M$ & $\begin{array}{c}\text { Epicentral } \\
\text { distance/km }\end{array}$ & $\begin{array}{l}\text { Variation from } \\
\qquad(\operatorname{Avg} \pm 2 \sigma)\end{array}$ \\
\hline \multirow[t]{5}{*}{ Amritsar } & $2007-06-06$ & $2007-06-14$ & 32.6 & 76.5 & 23.7 & 2.9 & 172 & $30.3 \%$ \\
\hline & 2007-08-06* & $2007-08-13$ & 31.6 & 77.2 & 2.5 & 2.4 & 199 & $23.1 \%$ \\
\hline & $2007-08-27^{*}$ & $2007-08-28$ & 30.7 & 76.1 & 14.8 & 2.9 & 138 & $7.7 \%$ \\
\hline & 2007-10-01 & $2007-10-04$ & 32.5 & 76.2 & 4.5 & 3.7 & 144 & $6.3 \%$ \\
\hline & $2007-12-06$ & $2007-12-06$ & 32.5 & 76.3 & & 2.9 & 151 & $9.4 \%$ \\
\hline \multirow[t]{3}{*}{ Dharamshala } & $2007-05-29$ & $2007-06-03$ & 31.4 & 77.9 & 22.3 & 3.3 & 175 & $10.2 \%$ \\
\hline & $2007-06-21 *$ & $2007-06-29$ & 31.0 & 78.1 & 10.0 & 2.6 & 175 & $1.0 \%$ \\
\hline & $2007-08-15^{*}$ & $2007-08-28$ & 30.7 & 76.1 & 14.8 & 2.9 & 167 & $43.0 \%$ \\
\hline \multirow[t]{15}{*}{ Dalhousie } & $2007-01-22 *$ & $2007-02-10$ & 31.7 & 78.2 & 14.6 & 2.0 & 230 & $23.8 \%$ \\
\hline & $2007-03-15$ & $2007-03-30$ & 31.9 & 77.3 & 6.5 & 3.4 & 145 & $1.2 \%$ \\
\hline & $2007-03-27$ & & & & & & & $5.3 \%$ \\
\hline & $2007-03-31$ & $2007-03-31$ & 31.5 & 77.4 & 10.0 & 2.3 & 180 & $12.3 \%$ \\
\hline & $2007-04-15$ & 2007-04-16 & 31.4 & 77.1 & 10.0 & 2.2 & 169 & $1.3 \%$ \\
\hline & $2007-06-21^{*}$ & $2007-06-29$ & 31.6 & 78.1 & 33.5 & 2.5 & 227 & $10.7 \%$ \\
\hline & 2007-07-09* & $2007-07-22$ & 33.0 & 78.2 & 15.0 & 5.0 & 210 & $56.4 \%$ \\
\hline & $2007-07-31$ & 2007-08-01 & 33.9 & 74.6 & 39.1 & 3.1 & 194 & $1.6 \%$ \\
\hline & $2007-08-05$ & 2007-08-07 & 31.2 & 78.0 & 10.0 & 3.5 & 245 & $2.1 \%$ \\
\hline & 2007-08-17 & $2007-08-27$ & 31.7 & 77.4 & 20.7 & 2.5 & 165 & $1.6 \%$ \\
\hline & $2007-08-20$ & & & & & & & $1.6 \%$ \\
\hline & $2007-09-13$ & $2007-09-16$ & 31.2 & 77.7 & 37.9 & 2.1 & 223 & $1.6 \%$ \\
\hline & $2007-10-16$ & $2007-10-19$ & 32.1 & 76.2 & 17.3 & 3.1 & 59 & $1.6 \%$ \\
\hline & $2007-10-30 *$ & 2007-11-01 & 77.4 & 31.4 & 7.3 & 2.7 & 208 & $52.6 \%$ \\
\hline & 2007-11-04 & $2007-11-21$ & 31.5 & 77.5 & 6.2 & 2.7 & 187 & $1.6 \%$ \\
\hline
\end{tabular}

*Negative anomaly. 
monitoring stations. The TDS observed at two stations (Amritsar and Dharamshala) shows negative anomalous value before the NW Himalayas event of magnitude 2.9 that occurred on August 28, 2007. This event is also correlated with the conductivity anomaly observed at Amritsar and Dharamshala. The negative anomalous behavior of TDS observed at two stations (Dharamshala and Dalhousie) was also observed prior to the NW Himalayas earthquake of magnitude 2.6 that occurred on June 29, 2007. At Amritsar and Dharamshala stations, the negative anomalous behavior of TDS was also observed prior to the NW Himalayas earthquake of magnitude 2.9 that occurred on August 15, 2007. The change in conductivity value prior to the event may be due to changes in groundwater dynamics, i.e., the variations in the velocity of liquid-phase fluids, which is resulted from strain processes associated with earthquakes (Plastino et al, 2002). The TDS anomaly may be interpreted as results of enhanced fluid-rocks interaction caused by stress induced permeability modification (Claesson et al, 2004). However, the detailed mechanism for these changes due to seismic activity still needs to be explored.

The conductivity does not show any change prior to the Uttarakashi earthquake of magnitude 5.0 that occurred on July 22, 2007, while the TDS shows negative anomalous behavior only at one station. Radon shows abnormal value in soil as well as water at all monitoring stations prior to this event (Kumar et al, 2009). Our results reveal that the values of conductivity and TDS in water do not show a regular trend prior to the earthquake events. The values sometimes increase or decrease or may not change before the occurrence of the earthquake. This behavior has also been reported by Kayal and Banerjee (1987) in case of resistivity measurement in soil in Shillong plateau of NE, India.

Correlation coefficients $(R)$ between conductivity/TDS anomaly $(A)$, epicentral distance $(D)$ and earthquake magnitude $(M)$ are evaluated from the above data. The amplitude of the anomaly is positively correlated with the magnitude and the epicentral distance with the value of 0.20 and 0.21 , respectively.

In a word, the changes in conductivity and/or TDS may occur prior to a seismic event; the amplitude of conductivity/TDS anomaly is positively correlated to magnitude and the epicentral distance of the earthquake.

Acknowledgements The work was supported by the MoES research project entitled Seismotectonic studies and Health Risk assessments in the Himalayas with Special Emphasis on Radon and Helium Emission under grant No. MoES/23(476)/SU/2004. Thanks are due to the Director Wadia from Institute of Himalayan Geology, Dehradun and IMD, New Delhi for providing the seismic data.

\section{References}

Barsukov O M (1972). Variations of electrical resistivity of mountain rocks connected with tectonic causes. Tectonophysics 14(3/4): 273-277.

Claesson L, Skelton A, Graham C, Dietl C and Morth M (2004). Hydrogeochemical changes before and after a major earthquake. Geology 32: 641-644.

Einarsson P, Theodorsson P, Hjartardottir A R and Guojonsson G I (2008). Radon changes associated with the earthquake sequence in June 2000 in the South Iceland Seismic Zone. Pure Appl Geophys 165: 63-74.

Gupta S K and Deshpande R D (2003). Dissolved helium and TDS in groundwater from Bhavanagar in Gujarat: Unrelated to seismic events between August 2000 and January 2001. Proc Indian Acad Sci (Earth Planet Sci) 112: $51-60$.

Hartmann J and Levy J K (2005). Hydrogeological and gasgeochemical earthquake precursors: A review for application. Natural Hazards 34: 279-304.

Italiano F, Martinelli G and Plescia P (2008). $\mathrm{CO}_{2}$ degassing over seismic areas: The role of mechanochemical production at the study case of Central Apennines. Pure Appl Geophys 165: 75-94.

Kayal J K and Banerjee B (1987). Anomalous behaviour of precursor resistivity in Shillong area, NE India. Geophysical Journal 94: 97-103.

Kumar A, Singh S, Mahajan S, Bajwa B S, Kalia R and Dhar S (2009). Earthquake precursory studies in Kangra valley of North West Himalayas, India, with special emphasis on radon emission. Appl Radiat Isotopes 67: 19041911.

Mazzella A and Morrison H F (1974). Electrical resistivity variations associated with earthquakes on the San Andreas fault. Science 185: 855-857.

Narayanpethkar A B, Vasanthi A and Mallick K (2001). Possible relationship between temporal electrical resistivity variation and occurrence of the earthquake of 30 September 1993 in Latur region, Maharashtra, India. Current Science 81: 1 224-1 231.

Narula P L and Shome S K (1992). Macroseismic studies of recent earthquakes in northwest Himalaya - A review. Current Science 62: 24-33.

Plastino W, Bella F, Catalano P G and Di Giovambattista R (2002). Radon ground water anomalies related to Umbria-Marche, September 26, 1997, earthquake. Geofisica Internacional 41: 369-375.

Seeber L and Armbruster J G (1981). Great detachment earthquakes along the Himalayan arc and international review. Am Geophys Union, Morris Ewing Series 4: 259-277.

Sidorenko A V, Sadovsky M A, Nersesov I L, Popov E A and Soloviev S L (1984). Soviet experience in earthquake prediction in the USSR and prospects for its development, Earthquake Prediction. In: Proc Int Symp on Earthquake Prediction. Terra Scientific Publications Co., Tokyo, 565-573.

Qian J (1984). Regional study of the anomalous change in apparent resistivity before the Tangshan earthquake $(M=7.8,1976)$ in China. Pure Appl Geophys 122: 901-920.

Walia V, Virk H S, Yang T F, Mahajan S, Walia M and Bajwa B S (2005). Earthquake prediction studies using radon as a precursor in N-W Himalayas, India: A case study. Terr Atmos Ocean Sci 16: 775-804.

Yamazaki Y (1975). Precursory and coseismic resistivity changes. Pure Appl Geophys 113: 219-227.

Yang T F, Walia V, Chyi L L, Fu C C, Chen C H, Liu T K, Song S R, Lee C Y and Lee $\mathrm{M}$ (2005). Variations of soil radon and thoron concentrations in a fault zone and prospective earthquakes in SW Taiwan. Radiat Meas 40: 496-502. 